\title{
Clinical Significance of KIAA1199 as a Novel Target for Gastric Cancer Drug Therapy
}

\author{
MASATAKA ONEYAMA ${ }^{1,2}$, NAOYA SAKAMOTO ${ }^{3}$, NAOHIDE OUE $^{3}$, YAYOI KIMURA ${ }^{4}$, \\ YUKIHIKO HIROSHIMA ${ }^{5}$, ITARU HASHIMOTO ${ }^{2}$, KENTARO HARA ${ }^{2}$, YUKIO MAEZAWA ${ }^{6}$, \\ KAZUKI KANO $^{1}$, TORU AOYAMA ${ }^{2}$, HIROHITO FUJIKAWA ${ }^{1}$, TAKANOBU YAMADA ${ }^{1}$, \\ HIROSHI TAMAGAWA ${ }^{2}$, NAOTO YAMAMOTO ${ }^{1}$, TAKASHI OGATA ${ }^{1}$, HARUHIKO $^{1}$ CHO $^{6}$, HIROYUKI ITO ${ }^{7}$, \\ NORIO YUKAWA ${ }^{2}$, MANABU SHIOZAWA ${ }^{1}$, TAKAKI YOSHIKAWA ${ }^{8}$, SOICHIRO MORINAGA $^{1}$, \\ YASUSHI RINO ${ }^{2}$, MUNETAKA MASUDA ${ }^{2}$, YOHEI MIYAGI ${ }^{5}$, WATARU YASUI ${ }^{3}$ and TAKASHI OSHIMA ${ }^{1}$ \\ ${ }^{1}$ Department of Gastrointestinal Surgery, Kanagawa Cancer Center, Yokohama, Japan; \\ ${ }^{2}$ Department of Surgery, Yokohama City University, Yokohama, Japan; \\ ${ }^{3}$ Department of Molecular Pathology, Hiroshima University Institute of Biomedical and Health Science, Hiroshima, Japan; \\ ${ }^{4}$ Advanced Medical Research Center, Yokohama City University, Yokohama, Japan; \\ ${ }^{5}$ Kanagawa Cancer Center Research Institute, Yokohama, Japan; \\ ${ }^{6}$ Department of Surgery, Tokyo Metropolitan Cancer and Infectious Disease Center Komagome Hospital, Tokyo, Japan; \\ ${ }^{7}$ Department of Respiratory Surgery, Kanagawa Cancer Center, Yokohama, Japan; \\ ${ }^{8}$ Department of Gastric Surgery, National Cancer Center Hospital, Tokyo, Japan
}

\begin{abstract}
Background/Aim: The KIAAl199 gene has been associated with cancer-cell proliferation, but its functions remain poorly studied. Here, we examined the clinical significance of the KIAA1199 mRNA levels in locally advanced gastric cancer (GC). Materials and Methods/Results: Using samples from 254 patients with stage II/III GC, we found significantly higher KIAA1199 levels in cancerous tissues compared to adjacent normal mucosa (ANM). There was no significant relationship between KIAA1199 expression and clinical features. Although overall survival rates (OSR) of patients, who underwent surgery did not correlate with KIAA1199 expression, patients who underwent adjuvant chemotherapy with S-1 and had high KIAA1199 levels displayed significantly lower OSR. KIAA1199 knock down (KIAA1199$K D)$ suppressed proliferation, invasiveness, and sensitivity of GC cells to 5-fluorouracil (5-FU). Conclusion: KIAA1199 expression appears to be a promising prognostic marker in patients with locally advanced GC, who underwent postoperative adjuvant chemotherapy with S-1. KIAA1199 may represent a novel target for GC pharmacotherapy.
\end{abstract}

Correspondence to: Takashi Oshima, Department of Gastrointestinal Surgery, Kanagawa Cancer Center, Yokohama, 2418515, Japan. Tel: +81 455202222, Fax: +81 455202202, e-mail: oshimat@kcch.jp

Key Words: KIAA1199, gastric cancer, prognostic factor, S-1.
Gastric cancer (GC) is the fifth most common cancer type $(1,033,701$ affected individuals in 2018) and accounts for the third highest number of cancer-related deaths $(781,631$ death cases in 2018) (1). In Japan, postoperative adjuvant S-1 chemotherapy is one of the standard treatments for locally advanced GC after radical resection (2-4). Fluorinatedpyrimidine is still the key drug for postoperative adjuvant chemotherapy against GC (5-7). However, such GC treatments are not sufficiently efficient $(3,6)$. Personalized postoperative adjuvant chemotherapy using biomarkers is a promising treatment strategy for improving outcomes of patients with locally advanced GC.

The KIAA1199 gene was discovered as an inner-earspecific gene encoding the KIAA1199 protein (8). KIAA1199 is located at chromosome band $15 \mathrm{q} 25.1$, the same region where the brain tumor-suppressor gene was mapped (9-11). Recent studies have reported that KIAA1199 repression attenuates $\mathrm{Wnt} / \beta$-catenin signaling and decreases the proliferation of colorectal cancer cells (12). Furthermore, our DNA microarray analysis showed a 10 -fold increase in KIAA1199 expression in GC tissue compared to adjacent normal mucosa (ANM). Here, we examined the clinical significance of KIAA1199 expression in locally advanced GC and its potential as a new target for anti-GC agents.

\section{Materials and Methods}

Patients and samples. The examined surgical samples of cancerous tissue and paired ANM were obtained from 254 patients with previously untreated stage II/III GC, who underwent radical 
resection. Tumor staging was evaluated using the 8 th edition of the International Union Against Cancer TNM classification for GC. The patients underwent gastrectomy at Yokohama City University between January 2002 and July 2007. Informed consent was obtained from each patient and the ethics committees of Yokohama City University approved the protocol prior to the study (approval number: 18-7A-4). Samples were embedded in optimal cutting temperature compound (Sakura Finetechnical Co., Ltd., Tokyo, Japan) and immediately stored at $-80^{\circ} \mathrm{C}$. None of the patients presented any other carcinomas.

RNA extraction and complementary DNA (cDNA) synthesis. Total RNA was extracted from GC tissue and ANM using TRIzol ${ }^{\mathrm{TM}}$ Reagent (Invitrogen, Carlsbad, CA, USA) according to the manufacturer's protocol. cDNA was synthesized using an iScript cDNA Synthesis Kit (Bio-Rad Laboratories, Hercules, CA, USA) according to the manufacturer's protocol and stored at $-20^{\circ} \mathrm{C}$.

Quantitative RT-PCR ( $q R T-P C R)$. qRT-PCR was performed in a total volume of $15 \mu \mathrm{l}$ containing iQ SYBR-Green Supermix (BioRad Laboratories), cDNA, and the following primers: sense primer 5'-GACCTCTCCATCCATCATAC-3' and antisense primer 5'-TTCCGTGAAGAAGCAGTG-3'. The oligonucleotide primers for the internal control $\beta$-actin were sense primer $5^{\prime}$ AGTTGCGTTACACCCTTTCTTGAC-3' and antisense primer 5'-GCTCGCTCCAACCGACTGC-3'. The PCR program consisted of: initial denaturation $\left(10 \mathrm{~min}\right.$ at $\left.95^{\circ} \mathrm{C}\right) ; 40$ cycles of cDNA denaturation $\left(10 \mathrm{~s}\right.$ at $\left.95^{\circ} \mathrm{C}\right)$, annealing $\left(10 \mathrm{~s}\right.$ at $60^{\circ} \mathrm{C}$ for KIAA 1199 and at $66^{\circ} \mathrm{C}$ for $\beta$-actin), and primer extension (20 s at $\left.72^{\circ} \mathrm{C}\right)$; and final extension $\left(10 \mathrm{~min}\right.$ at $\left.72^{\circ} \mathrm{C}\right)$. Melting curves were analyzed to distinguish specific from nonspecific products and primer dimers. mRNA expression was evaluated by a standard curve consisted of three concentrations of $\beta$-actin cDNA (Clontech Laboratories, Inc., CA, USA). The average of triplicates of each measurement is presented.

Immunohistochemical analysis. Formalin-fixed and paraffinembedded GC tissue sections were deparaffinized and soaked in 10 $\mathrm{mM}$ sodium citrate buffer at $121^{\circ} \mathrm{C}$ for $15 \mathrm{~min}$ to retrieve cell antigens. The sections were blocked and incubated overnight at $4^{\circ} \mathrm{C}$ with primary polyclonal anti-KIAA1199 antibody (Atlas Antibodies, Stockholm, Sweden) at 1:100 dilution. Peroxidase-labeled polymer (EnVision+/HRP, rabbit, DAKO, Glostrup, Denmark) was used to detect antigen-antibody reaction. All sections were counterstained with hematoxylin. Samples were observed under an upright microscope (BX43; Olympus, Tokyo, Japan).

MKN45 cell transfection with KIAA1199-targeting smallinterfering RNAs (siRNAs). Transient transfection of human GC cell line (MKN45) with KIAA1199-targeting siRNAs was performed as previously described (13). Briefly, MKN45 cells were plated at a density of $1.0 \times 10^{4}$ cells/well in a micro-plate and the optimal siRNA concentration was determined. The cells were transfected using KIAA1199-targeting SMART pool siRNA (Dharmacon, Lafayette, CO, USA), Lipofectamine RNAiMAX (Invitrogen), and Opti-MEM I (Invitrogen). KIAA1199-KD was evaluated by qRT-PCR and western blotting. An optimal working concentration of siRNA was used to perform cell proliferation assays. All siRNA transfection experiments were performed three times.
Western blotting. Gastric cancer cells were washed twice with phosphate-buffered saline and lysed by incubation in Lysis A buffer containing $1 \%$ Triton $\mathrm{X}-100,20 \mathrm{mM}$ Tris- $\mathrm{HCl}(\mathrm{pH} 7.0), 50 \mathrm{mM}$ sodium chloride, $10 \mathrm{mM}$ sodium pyrophosphate, $50 \mathrm{mM}$ sodium fluoride, $5 \mathrm{mM}$ EDTA, $1 \mathrm{mM}$ sodium orthovanadate, and a phosphatase inhibitor cocktail (Sigma-Aldrich, St. Louis, MO, USA). The proteins were resolved using SDS-PAGE and transferred onto a PVDF membrane (Invitrogen). After blocking, the membranes were exposed to antiKIAA1199 (Abcam plc, Cambridge, UK) and anti- $\beta$-actin primary antibodies (Abcam plc). The cells were then washed followed by incubation with goat anti-rabbit IgG H\&L (HRP) secondary antibody (Abcam plc). Finally, the proteins were visualized using an ECL Western Blotting Detection System (GE Healthcare, Buckinghamshire, UK).

Cell proliferation and invasiveness assays. Proliferation of KIAA1199-KD and control MKN45 cells was compared at 24, 48, and $96 \mathrm{~h}$ after plating $1.0 \times 10^{6}$ cells/well in a microplate. Cell proliferation was assessed using the MTT-assay [3-(4, 5dimethylthiazol-2-yl)2,5-diphenyltetrazolium bromide, Roche] with a microplate reader (ImmunoMini NJ-2300, InterMed, Japan) with a readout at $540 \mathrm{~nm}$. Cell invasiveness was compared at 6, 24, 48, and $72 \mathrm{~h}$ after plating $1.0 \times 10^{6}$ cells/well in RPMI 1640 medium with no serum in the upper chamber of a Transwell insert (pore diameter, 8 $\mu \mathrm{m}$; Chemicon, Temecula, CA, USA) coated with Matrigel. Medium containing $10 \%$ serum was added to the bottom chamber. After 24 and $48 \mathrm{~h}$, cells in the upper chamber were removed by scraping and the cells remaining in the lower chamber were stained with CyQuant GR dye (Chemicon) to assess the number of cells.

Analyzing cell sensitivity to 5-FU. KIAA1199-KD and control MKN45 cells were plated at $1.0 \times 10^{6}$ cells/well and after $24 \mathrm{~h}$ they were treated with $5 \mu \mathrm{M} 5$-FU for $6,24,48$, and $72 \mathrm{~h}$. An MTT-assay was used to detect changes in 5-FU sensitivity of the cells.

Statistical analysis. Expression levels of KIAA1199 were compared between GC tissue and ANM using the Wilcoxon signed-rank test. The relationships between gene expression and clinical factors like age, gender, tumor size, histological type, depth of invasion, lymph node metastasis, disease stage, lymphatic invasion, and venous invasion were evaluated using the $\chi^{2}$ test. The postoperative OSR was analyzed using the Kaplan-Meier method and differences in OSR were assessed using the log-rank test. A Cox proportionalhazards regression model was used for univariate and multivariate analyses. Results of MTT and invasion assays were evaluated using the Mann-Whitney $U$-test. All statistical analyses were performed using IBM SPSS Statistics 18.0 (SPSS, Inc., Chicago, IL, USA). Two-sided $p$-values were calculated and a difference was considered significant when $p<0.05$.

\section{Results}

Comparison of KIAA1199 expression between GC tissue and ANM. KIAA1199 levels were significantly higher in cancer tissue than in ANM $(p<0.0001$; Figure 1$)$.

KIAA1199 expression in GC tissue. Positive staining for KIAA1199 was observed in the cytoplasm and it was markedly more intense in GC cells than in stromal cells in both differentiated and undifferentiated GC types (Figure 2). 


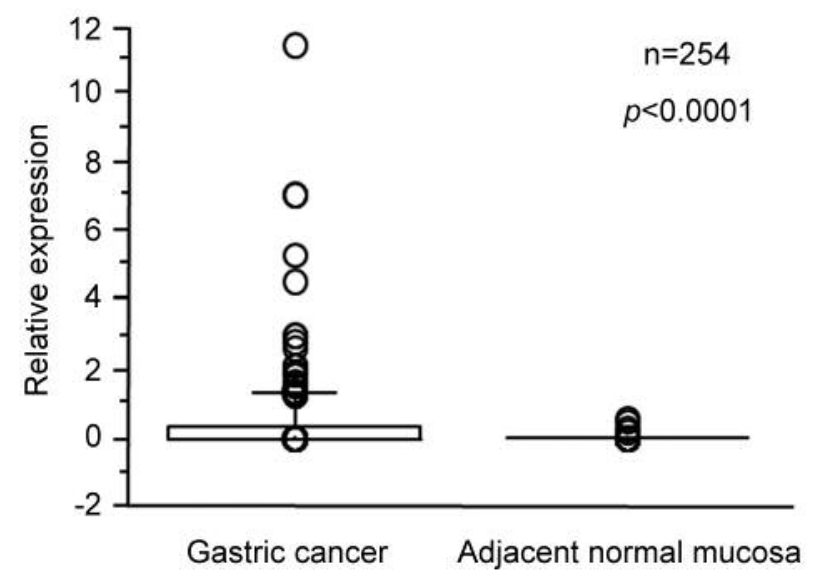

Figure 1. Comparison of KIAA1199 mRNA expression levels between GC tissue and ANM $(p<0.0001)$. Box boundaries indicate the 25th and 75 th percentiles of the observed values and capped bars, the 10th and 90 th percentiles. The solid line indicates the median.

Relationship between KIAA1199 expression levels and clinical characteristics. KIAA1199 expression levels were categorized as low or high according to the median value in all samples and the relationship with clinical characteristics is summarized in Table I. There was no significant correlation between KIAA1199 expression and any of the clinical features.

Correlation between KIAA1199 expression levels and OSR. Opposite correlation between OSR and KIAA1199 expression was observed in patients, who had received adjuvant chemotherapy with S-1. High expression of KIAA1199 was associated with significantly lower OSR ( $p=0.0015$; Figure 3A). However, OSR was not affected by the KIAA1199 levels in patients who underwent surgery alone (Figure 3B). The postoperative relapse-free survival was significantly lower in patients with high compared to low KIAA1199 levels ( $p=0.0047$; Figure 3C).

Univariate and multivariate analyses of the relationships between clinical factors, KIAA1199 expression, and outcomes. Univariate analysis revealed that serosal invasion and KIAA1199 expression were related to the outcomes. Multivariate Cox proportional hazards regression analysis showed that only KIAA1199 expression was related to the outcomes $(p=0.0074$; Table II).

Changes in invasiveness and proliferative activity in KIAA1199-KD GC cells. KIAA1199-KD in GC cells suppressed their proliferation and invasiveness 24,48 , and $96 \mathrm{~h}$ after plating $(p<0.05$; Figure $4 \mathrm{~A}$ and B).
Table I. The relationship between KIAA1199 gene expression and clinical characteristics.

\begin{tabular}{|c|c|c|c|}
\hline \multirow[t]{2}{*}{ Variables/categories } & \multicolumn{2}{|c|}{ KIAA1199 expression } & \multirow[t]{2}{*}{$p$-Value } \\
\hline & Low $(n=74)$ & High $(n=73)$ & \\
\hline Age & $66.84 \pm 7.76$ & $64.53 \pm 10.84$ & 0.101 \\
\hline \multicolumn{4}{|l|}{ Gender } \\
\hline Male & 51 & 50 & 1 \\
\hline Female & 23 & 23 & \\
\hline \multicolumn{4}{|l|}{ Size } \\
\hline$<6.5 \mathrm{~cm}$ & 35 & 35 & 1 \\
\hline$\geq 6.5 \mathrm{~cm}$ & 39 & 38 & \\
\hline \multicolumn{4}{|l|}{ Histologic type } \\
\hline Differentiated type & 29 & 28 & 1 \\
\hline Undifferentiated type & 45 & 45 & \\
\hline \multicolumn{4}{|l|}{ Depth of invasion } \\
\hline $\mathrm{T} 1$ & 0 & 3 & 0.321 \\
\hline $\mathrm{T} 2$ & 12 & 9 & \\
\hline $\mathrm{T} 3$ & 17 & 18 & \\
\hline $\mathrm{T} 4$ & 45 & 43 & \\
\hline \multicolumn{4}{|l|}{ Stage } \\
\hline II & 24 & 19 & 0.469 \\
\hline III & 50 & 54 & \\
\hline \multicolumn{4}{|l|}{ Lymph node metastasis } \\
\hline Absent & 12 & 8 & 0.471 \\
\hline Present & 62 & 65 & \\
\hline \multicolumn{4}{|l|}{ Lymphatic invasion } \\
\hline Absent & 14 & 21 & 0.179 \\
\hline Present & 60 & 52 & \\
\hline \multicolumn{4}{|l|}{ Venous invasion } \\
\hline Absent & 18 & 18 & 1 \\
\hline Present & 56 & 55 & \\
\hline
\end{tabular}

Changes in sensitivity of KIAA1199-KD GC cells to 5-FU. KIAA1199-KD GC cells appeared more sensitive to 5-FU and exhibited significantly decreased proliferation compared to control cells $6 \mathrm{~h}$ after 5 -FU administration $(p<0.05)$. This effect was maintained until $96 \mathrm{~h}$ after 5-FU administration (Figure 4C).

\section{Discussion}

The aim of this study was to reveal the clinical significance of KIAA1199 expression in locally advanced GC and its potential as a new target for anti-GC agents.

Several previous have reported that KIAA1199 mRNA expression is higher in colorectal (12), breast (14), and GC (15) cancer tissues than in normal tissues. Consistent with these findings, we observed higher KIAA1199 mRNA expression in GC tissue than in paired ANM.

It has been reported that increased KIAA1199 mRNA expression correlates with tumor metastasis nodes in nonsmall cell lung cancer (16). In a previous report, KIAA1199 

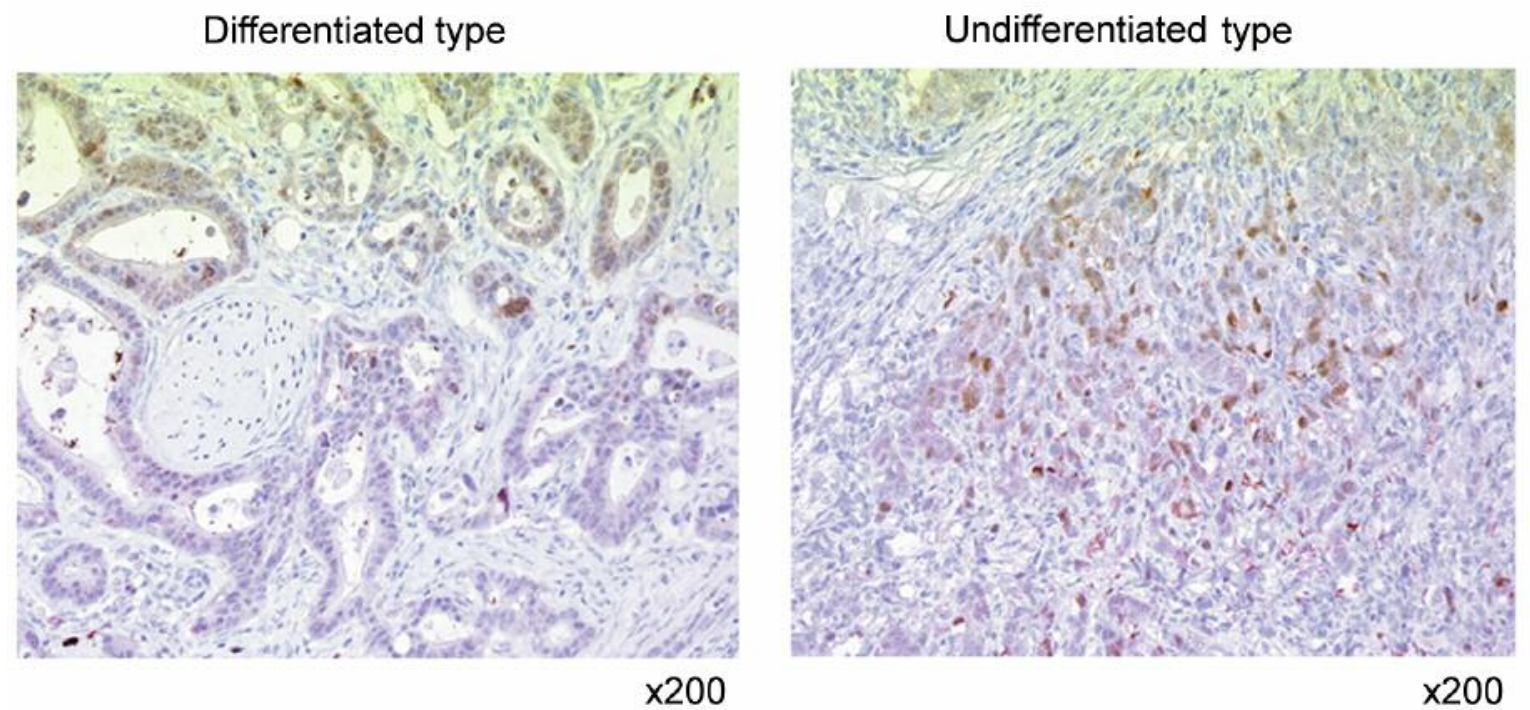

Figure 2. Immunohistochemistry of KIAA1199 protein, mainly located in the cytoplasm. Left panel shows the KIAA1199 staining in differentiated and the right in undifferentiated GC cells.

Table II. Univariate and multivariate Cox proportional hazards analyses of the relationship between survival, KIAA1199 gene expression, and clinical characteristics in the group that received $S$-1 adjuvant chemotherapy.

\begin{tabular}{|c|c|c|c|c|c|c|c|}
\hline \multirow[t]{2}{*}{ Variables/categories } & \multirow[t]{2}{*}{$\mathrm{n}$} & \multicolumn{3}{|c|}{ Univariate analysis } & \multicolumn{3}{|c|}{ Multivariate analysis } \\
\hline & & Hazard ratio & $95 \% \mathrm{CI}$ & $p$-Value & Hazard ratio & $95 \% \mathrm{CI}$ & $p$-Value \\
\hline \multicolumn{8}{|l|}{ Age (years) } \\
\hline$<70$ & 96 & 1 & & 0.7688 & & & \\
\hline$\geq 70$ & 51 & 1.112 & $0.547-2.263$ & & & & \\
\hline \multicolumn{8}{|l|}{ Gender } \\
\hline Female & 46 & 1 & & 0.6495 & & & \\
\hline Male & 101 & 1.185 & $0.570-2.463$ & & & & \\
\hline \multicolumn{8}{|l|}{ Histological type } \\
\hline Differentiated type & 56 & 1 & & 0.8994 & & & \\
\hline Undifferentiated type & 91 & 1.052 & $0.514-2.155$ & & & & \\
\hline \multicolumn{8}{|l|}{ Tumor size, mm } \\
\hline$<65 \mathrm{~mm}$ & 70 & 1 & & 0.0922 & & & \\
\hline$\geq 65 \mathrm{~mm}$ & 77 & 1.795 & $0.990-3.546$ & & & & \\
\hline \multicolumn{8}{|l|}{ Serosa invasion } \\
\hline Absent & 59 & 1 & & 0.0458 & 1 & $1.000-4.566$ & 0.05 \\
\hline Present & 88 & 2.169 & $1.014-4.630$ & & 2.137 & & \\
\hline \multicolumn{8}{|l|}{ Lymph node metastasis } \\
\hline Absent & 20 & 1 & & 0.3011 & & & \\
\hline Present & 127 & 1.869 & $0.571-6.098$ & & & & \\
\hline \multicolumn{8}{|l|}{ Venous invasion } \\
\hline Absent & 111 & 1 & & 0.1899 & & & \\
\hline Present & 36 & 1.799 & $0.748-4.329$ & & & & \\
\hline \multicolumn{8}{|l|}{ Lymphatic invasion } \\
\hline Absent & 112 & 1 & & 0.5287 & & & \\
\hline Present & 35 & 1.304 & $0.571-2.976$ & & & & \\
\hline \multicolumn{8}{|l|}{ KIAA1199 gene expression } \\
\hline High & 73 & 1 & & 0.0068 & 1 & & 0.0074 \\
\hline Low & 74 & 2.891 & $1.339-6.25$ & & 2.865 & $1.326-6.173$ & \\
\hline
\end{tabular}

CI: Confidence interval. Bold values indicate statistical significance at $p<0.05$. 

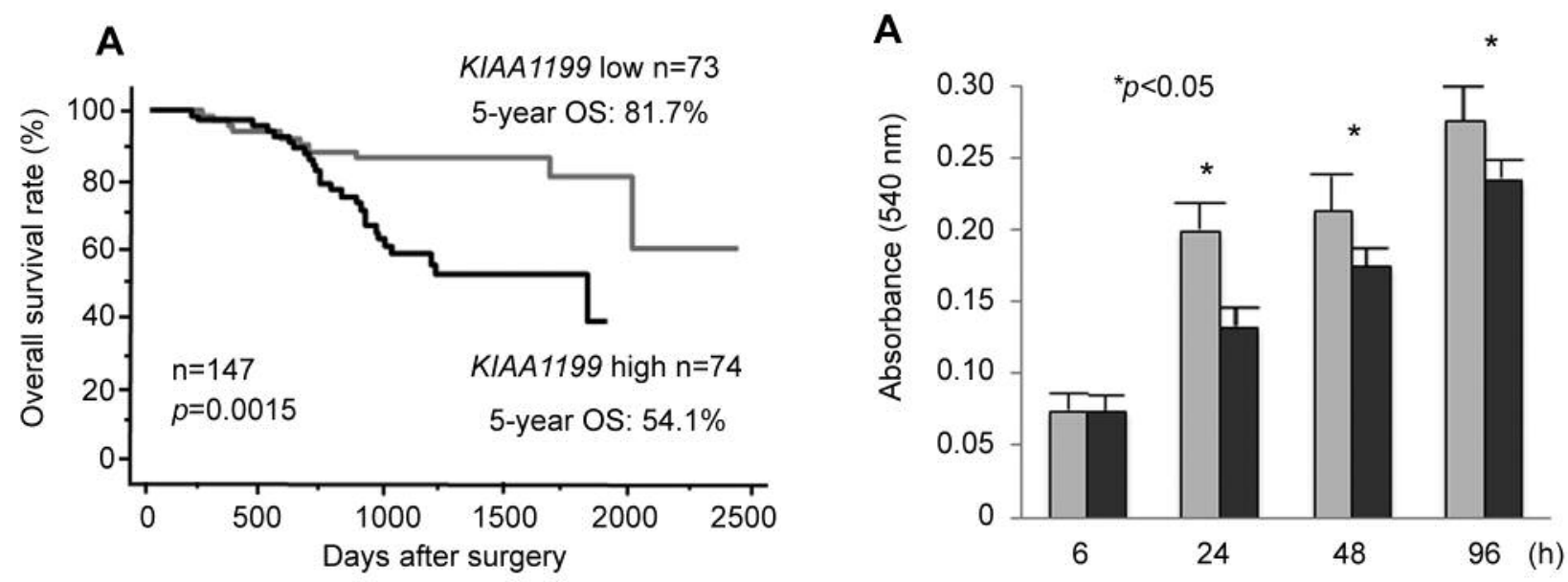

B
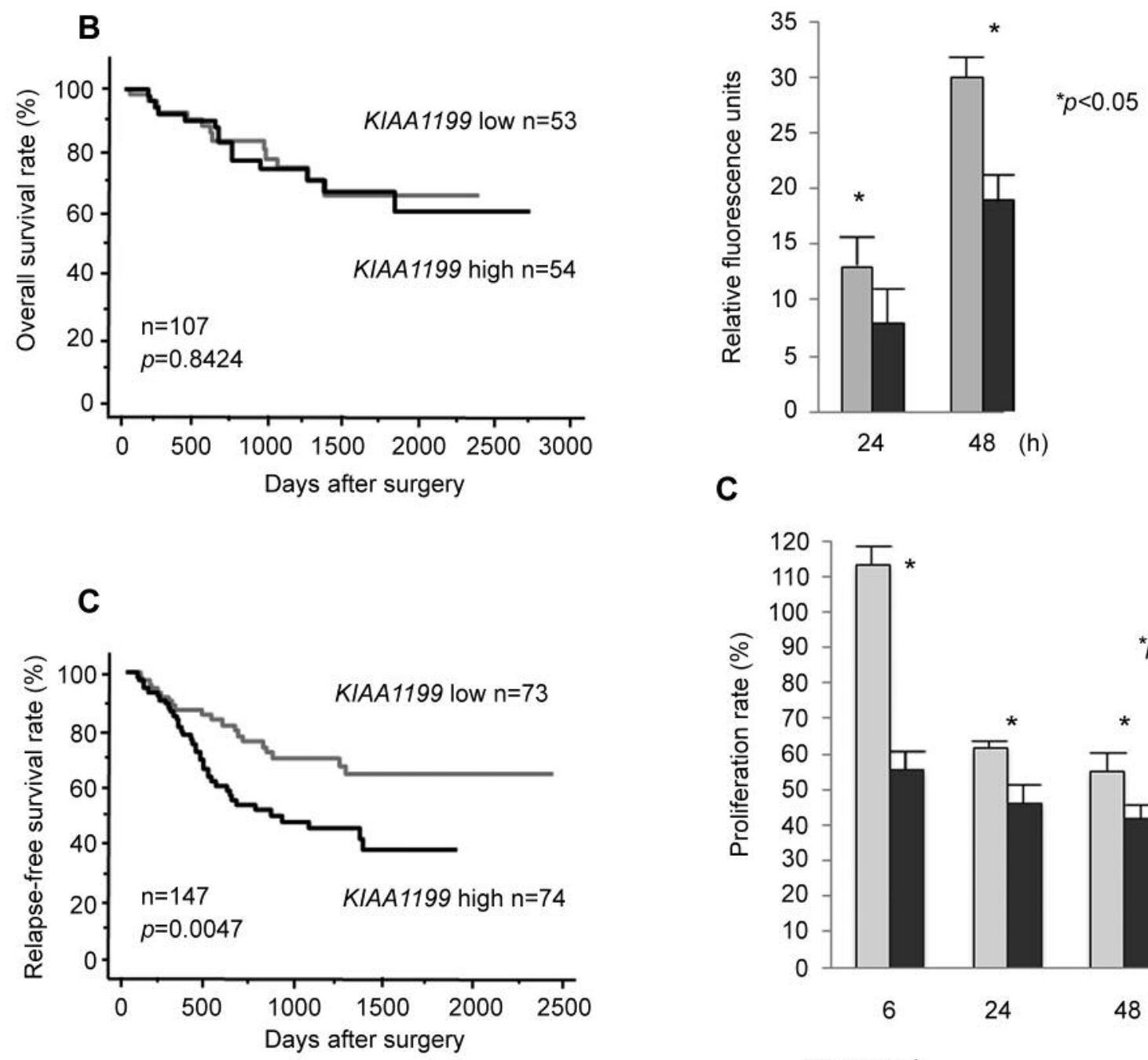

Figure 3. The relationship between KIAA1199 mRNA expression levels and cell survival in patients given adjuvant chemotherapy with $S-1$ $(p=0.0015)(A)$; in patients with surgery alone $(p=0.8424)(B)$, or in patients who received adjuvant chemotherapy with $S-1(p=0.0047)(C)$. OS: Overall survival.

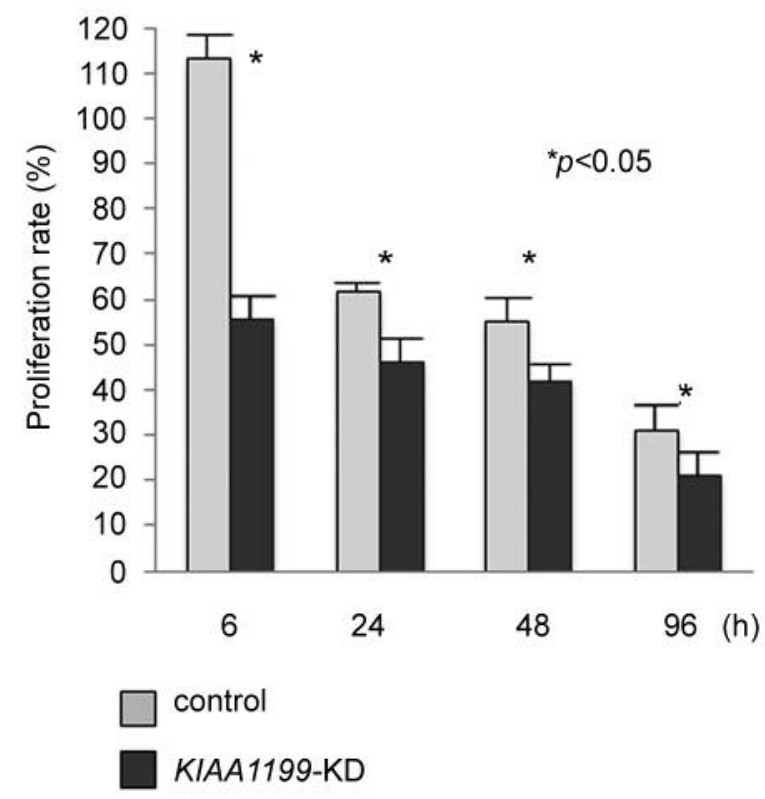

Figure 4. Changes in invasiveness (A), proliferation $(B)$, and sensitivity to 5-FU (C) in KIAA1199-KD GC cells. 
overexpression was correlated with lymph node metastasis, distant metastasis, and peritoneal dissemination in GC (15). However, we found no significant relationship between KIAA1199 mRNA expression levels and any of the tested clinical features. In a previous report, KIAA1199 mRNA overexpression was correlated with poor GC prognosis (15). Here, high KIAA1199 mRNA expression was associated with poor outcomes in patients who underwent postoperative adjuvant chemotherapy with S-1 or adjuvant chemotherapy with S-1 alone, but not surgery alone. Furthermore, univariatemultivariate Cox proportional hazards model analysis showed that only high KIAA1199 mRNA expression in cancer tissue was an independent poor prognostic factor in patients who underwent surgery and postoperative adjuvant chemotherapy with S-1. These results suggested that KIAA1199 mRNA overexpression could lead to $\mathrm{S}-1$ resistance. Indeed, we found that KIAA1199-KD in GC cells reduced their proliferative ability and invasiveness and increased sensitivity to 5-FU. To our knowledge, this is the first report to demonstrate that KIAA1199 is related to 5-FU resistance in GC patients.

The relationship between KIAA1199 mRNA expression and the poor outcomes in patients with locally advanced GC who underwent postoperative adjuvant chemotherapy with $S-1$ have yet to be fully elucidated. Our results along with previous studies suggest that four main factors are involved. First, KIAA1199 expression is related to the proliferative ability of cancer cells via the Wnt/ $\beta$-catenin pathway $(12,17)$. Second, it has been reported that KIAA1199 promotes the release of calcium from the endoplasmic reticulum, which increases protein kinase $\mathrm{C} \alpha$ activity that plays an important role in cell migration and invasion (18). Third, KIAA1199 promotes epithelial mesenchymal transition via epidermal growth factor receptor signal transmission (19). Epithelial mesenchymal transition is regulated by transforming growth factor- $\beta$, which promotes cancer cell metastasis and drug-resistance (20). Finally, we found that KIAA1199 may be associated with GC cell resistance to 5-FU. Taken together, these mechanisms suggest that high expression of KIAA1199 mRNA in cancer tissue results in increased proliferation, invasion, cell migration, and chemotherapy resistance. This was associated with poor outcomes in patients with locally advanced GC, who underwent postoperative adjuvant chemotherapy with S-1.

Our study had several limitations. First, we only measured KIAA1199 mRNA expression in GC tissue and we examined the relationship between mRNA expression in GC tissue and clinicopathological features or outcomes. Considering the clinical utility of KIAA1199 as a biomarker, the relationship between its mRNA and protein levels should be examined using the same specimens. Second, GC tissues are heterogeneous and the mRNA was extracted from a GC tissue sample $1 \mathrm{~cm}^{2} \times 10 \mu \mathrm{m} \times 3$ in size, including the deepest part, which means that this sample does not completely represent the characteristics of the entire tumor.
In conclusion, KIAA1199 mRNA expression may be a useful prognostic marker in patients with locally advanced GC, who undergo postoperative adjuvant chemotherapy with S-1. KIAA1199 may be a new target for GC pharmacotherapy because of its association with 5-FU resistance.

\section{Conflicts of Interest}

The Authors have no conflicts of interest to declare regarding this study.

\section{Authors' Contributions}

The study presented here was carried out in collaboration with all the Authors. Masataka Oneyama and Naoya Sakamoto contributed to the design, protocol creation, experiments, analysis of data, and writing of the manuscript. Naohide Oue contributed to the design. Yayoi Kimura contributed to the protocol creation and analysis of the data. Yukihiko Hiroshima contributed to the analysis of data. Itaru Hashimoto, Kentaro Hara, Yukio Maezawa, Kazuki Kano, Toru Aoyama, Hirohito Fujikawa, Takanobu Yamada, Hiroshi Tamagawa, Naoto Yamamoto, Takashi Ogata, Haruhiko Cho, Hiroyuki Ito, Norio Yukawa, Manabu Shiozawa, Takaki Yoshikawa, Soichiro Morinaga, and Yasushi Rino contributed to acquisition of samples. Munetaka Masuda contributed to writing of the manuscript. Yohei Miyagi contributed to the design, protocol creation, and writing of the manuscript. Wataru Yasui contributed to the design and writing of the manuscript. Takashi Oshima contributed to the design, protocol creation, analysis of data, acquisition of samples, and writing of the manuscript. All Authors read and approved the final manuscript.

\section{Acknowledgements}

The Authors thank Kazue Yoshihara for her technical support.

\section{References}

1 Bray F, Ferlay J, Soerjomataram I, Siegel RL, Torre LA and Jemal A: Global cancer statistics 2018: GLOBOCAN estimates of incidence and mortality worldwide for 36 cancers in 185 countries. CA Cancer J Clin 68: 394-424, 2018. PMID: 30207593. DOI: 10.3322/caac.21492

2 Sakuramoto S, Sasako M, Yamaguchi T, Kinoshita T, Fujii M, Nashimoto A, Furukawa H, Nakajima T, Ohashi Y, Imamura H, Higashino M, Yamamura A, Kurita A and Arai K: Adjuvant chemotherapy for gastric cancer with S-1, an oral fluoropyrimidine. N Engl J Med 357: 1810-1820, 2007. PMID: 17978289. DOI: 10.1056/NEJMoa072252

3 Sasako M, Sakuramoto S, Katai H, Kinoshita T, Furukawa H, Yamaguchi T, Nashimoto A, Fujii M, Nakajima T and Ohashi: Five-year outcomes of a randomized phase III trial comparing adjuvant chemotherapy with S-1 versus surgery alone in stage II or III gastric cancer. J Clin Oncol 29: 4387-4393, 2011. PMID: 22010012. DOI: $10.1200 /$ JCO.2011.36.5908

4 Japanese Gastric Cancer Association: Japanese gastric cancer treatment guidelines 2014 (ver. 4). Gastric Cancer 20: 1-19, 2017. PMID: 27342689. DOI: 10.1007/s10120-016-0622-4 
5 Bang YJ, Kim YW, Yang HK, Chung HC, Park YK, Lee KH, Lee KW, Kim YH, Noh SI, Cho JY, Mok YJ, Kim YH, Ji J, Yeh TS, Button P, Sirzén F and Noh SH: Adjuvant capecitabine and oxaliplatin for gastric cancer after D2 gastrectomy (CLASSIC): a phase 3 open-label, randomised controlled trial. Lancet 379: 315-321, 2012. PMID: 22226517. DOI: 10.1016/S01406736(11)61873-4

6 Noh SH, Park SR, Yang HK, Chung HC, Chung IJ, Kim SW, Kim HH, Choi JH, Kim HK, Yu W, Lee JI, Shin DB, Ji J, Chen JS, Lim Y, Ha S and Bang YJ; CLASSIC trial investigators: Adjuvant capecitabine plus oxaliplatin for gastric cancer after D2 gastrectomy (CLASSIC): 5-year follow-up of an open-label, randomised phase 3 trial. Lancet Oncol 15: 1389-1396, 2014. PMID: 25439693. DOI: 10.1016/S1470-2045(14)70473-5

7 Yoshida K, Kodera Y, Kochi M, Ichikawa W, Kakeji Y, Sano T, Nagao N, Takahashi M, Takagane A, Watanabe T, Kaji M, Okitsu H, Nomura T, Matsui T, Yoshikawa T, Matsuyama J, Yamada M, Ito S, Takeuchi $M$ and Fujii $M$ : Addition of docetaxel to oral fluoropyrimidine improves efficacy in patients with stage III gastric cancer: Interim Analysis of JACCRO GC07, a Randomized Controlled Trial. J Clin Oncol 37: 1296-1304, 2019. PMID: 30925125. DOI:10.1200/JCO.18.01138

8 Abe S, Usami S and Nakamura Y: Mutations in the gene encoding KIAA1199 protein, an inner-ear protein expressed in Deiters' cells and the fibrocytes, as the cause of nonsyndromic hearing loss. J Hum Genet 48: 564-567, 2003. PMID: 14577002. DOI: $10.1007 / \mathrm{s} 10038-003-0079-2$

9 Dash DP, Silvestri G and Hughes AE: Fine mapping of the keratoconus with cataract locus on chromosome 15q and candidate gene analysis. Mol Vis 12: 499-505, 2006. PMID: 16735990 .

10 Michishita E, Garcés G, Barrett JC and Horikawa I: Upregulation of the KIAA1199 gene is associated with cellular mortality. Cancer Lett 28(239): 71-77, 2006. PMID: 16157444. DOI: $10.1016 /$ j.canlet.2005.07.028

11 Usami S, Wagatsuma M, Fukuoka H, Suzuki H, Tsukada K, Nishio S, Takumi Y and Abe S: The responsible genes in Japanese deafness patients and clinical application using Invader assay. Acta Otolaryngol 128: 446-454, 2008. PMID: 18368581. DOI: $10.1080 / 00016480701785046$

12 Birkenkamp-Demtroder K, Maghnouji A, Mansilla F, Thorsen K, Andersen C L, Øster B, Hahn S and Ørntoft TF: Repression of KIAA1199 attenuates Wnt-signalling and decreases the proliferation of colon cancer cells. Br J Cancer 105: 552-561, 2011. PMID: 21772334. DOI: 10.1038/bjc.2011.268

13 Lin J, Raoof DA, Wang Z, Lin MY, Thomas DG, Greenson JK, Giordano TJ, Orringer MB, Chang AC, Beer DG and Lin L: Expression and effect of inhibition of the ubiquitin-conjugating enzyme E2C on esophageal adenocarcinoma. Neoplasia 8: 10621071, 2006. PMID: 17217624. DOI: 10.1593/neo.05832
14 Kuscu C, Evensen N, Kim D, Hu YJ, Zucker S and Cao J: Transcriptional and epigenetic regulation of KIAA1199 gene expression in human breast cancer. PLoS One 7: e44661, 2012. PMID: 22970280. DOI: 10.1371/journal.pone.0044661

15 Matsuzaki S, Tanaka F, Mimori K, Tahara K, Inoue H and Mori M: Clinicopathologic significance of KIAA1199 overexpression in human gastric cancer. Ann Surg Oncol 16: 2042-2051, 2009. PMID: 19434458. DOI: 10.1245/s10434-009-0469-6

16 Deng F, Lei J, Zhang X, Huang W, Li Y and Wu D: Overexpression of KIAA1199: An independent prognostic marker in non-small cell lung cancer. J Cancer Res Ther 13: 664-668, 2017. PMID: 28901311. DOI: $10.4103 /$ jcrt.JCRT -61_17

17 Sabates-Bellver J, Van der Flier LG, de Palo M, Cattaneo E, Maake C, Rehrauer H, Laczko E, Kurowski MA, Bujnicki JM, Menigatti M, Luz J, Ranalli TV, Gomes V, Pastorelli A, Faggiani R, Anti M, Jiricny J, Clevers H and Marra G: Transcriptome profile of human colorectal adenomas. Cancer Res 5: 1263-1275, 2007. PMID: 18171984. DOI: 10.1158/1541-7786.MCR-070267

18 Evensen NA, Kuscu C, Nguyen HL, Zarrabi K, Dufour A, Kadam P, Hu YJ, Pulkoski-Gross A, Bahou WF, Zucker S and Cao J: Unraveling the role of KIAA1199, a novel endoplasmic reticulum protein, in cancer cell migration. J Natl Cancer Inst 105: 1402-1416, 2013. PMID: 23990668. DOI: 10.1093/ jnci/djt224

19 Shostak K, Zhang X, Hubert P, Göktuna S, Jiang Z, Klevernic I, Hildebrand J, Roncarati P, Hennuy B, Ladang A, Somja J, Gothot A, Close P, Delvenne P and Chariota A: NF- $x$ B-induced KIAA1199 promotes survival through EGFR signaling. Nat Commun 5: 5232, 2014. PMID: 25366117. DOI: 10.1038/ ncomms6232

20 Singh A and Settleman J: EMT, cancer stem cells and drug resistance: an emerging axis of evil in the war on cancer. Oncogene 29: 4741-4751, 2010. PMID: 20531305. DOI: 10.1038/onc. 2010.215
Received October 21, 2019

Revised November 3, 2019

Accepted November 4, 2019 